\title{
尿管結紮解除後の腎機能の恢復(実験的研究)
}

\author{
北海道大学医学部泌尿器科教室 清 水 隆秀
(主任: 辻一郎教授)

\section{RECOVERY OF THE RENAL FUNCTION AFTER THE RELEASE \\ OF COMPLETE URETERAL LIGATION} \\ (EXPERIMENTAL STUDY)
}

\author{
Takahide Shimizu \\ From the Urology Department, Medical Faculty, Hokkaido University
}

(Director: Prof. I. Tsuji)

緒言

水腎症の病態生理注極めて複雜である・実験的水腎症 及びその通過障害除去後の, 腎上部尿路の構造機能を研 究した論文淰，古来枚挙にいとまがない程であり，特に Hinman 一派の多年に亘る研究付有名である。

然し乍ら，今日に至るもな抆不明の事項や，再検傠を 要すべき点妙なくない.

一定期間の尿管結禁による完全通過障害を除去した場 合, 当磅腎がごの程度迄恢復するかの問題は臨床上重大 であるが，この問題を新らしい腎クリアランス法を用い て, 分節的に, 且つ可なり正確度をもつて数量的に標示 しょうとしたのは，Kerr (1954，1956) の報告及び当 敎室の渡井 (1957) の報告を及るのみである。

Kerr 及び渡井は, 犬の一側尿管を 1 乃至 4 週間結紮 し, 解除後の腎機能を追求しているが, 私も同様犬を用 いて, 短期間の 1 日乃至 5 日間方ら, 長期間は 5 万至 11 週迄, 一側尿管を結紮し, 乙れを解除後尿管皮膚庵々な して, 以後の恢復状態を, チ才硫酸ソーダクリアランス (CsTs), パラアミノ馬尿酸ソーダクリアランス ( $\left.\mathrm{C}_{\mathrm{PAH}}\right)$, $\mathrm{PAH}$ 尿細管分泌極量 (TMPAH) 及び PSP 排泄試験で 測定した (15分值).

\section{実験方法}

体重 8〜 23kgの雜種成犬雌28頭を用いた. クリアラン ス測定24時間前より絶食させるが，水は自由に飲末せ た. チオペンタールソーダ体重毎 $\mathrm{kg} 0.03 \mathrm{~g}$ によ静脈麻 醉を行い,クリアランス測定前に約 $300 〜 500 \mathrm{cc}$ 温水 を胃カテーテルで飲宗せ, 更に体重に応じて生理的食塩 水約 200〜 300cc 右肢静脈より点滴注入した. 引続き $10 \%$ チ硫酸ソーダ20〜 $40 \mathrm{cc}, 20 \%$ パラアミノ馬尿酸ソ
一ダ 6 〜2cc及び生理的食塩水学混合して, 大凡 200 $300 \mathrm{cc}$ 己しをもの, 最初の5 分間は $5 \mathrm{cc} /$ 分, 以後 3 cc/分の速度で右肢静脈より点滴し, 約 20 分後膀胱安力 テーテルを用いて完全に空にする.排尿10分後点滴の対 側の肢静脈より採血し，20分後再び膀胱尿を完全に採取 する。

クリアランス値の計算は $\mathrm{C}=\mathrm{UV} / \mathrm{P}$ となる。Vは 1 分 間尿量cc, Uは尿中 PAH或怯 STS 濃度mg/dl, P 漿中 PAH或は STS 濃度mg/dlで, 此の際 PAH のPは: 1〜 $5 \mathrm{mg} / \mathrm{dl} \mathrm{STS}$ は10〜20mg/dlが適当である.

TmPAH は引続き行い, $20 \% \mathrm{PAH}$ 液10１5ccを約 10 分間で点滴器のゴム管内学通して静脈内に注入し, 一方 イルリガートル内の残液約 100cck対して20\% PAH 15 cc学加えて, 1 分間 $3 \mathrm{cc}$ 速度で点滴注入娄行つた. 20 分経つて办ら膀胱を空虚にし, 採血採尿等の操作を行つ た。

第 1 表 対照正常犬「ク」值 (Per $\mathrm{m}^{2}$ body S.A)

\begin{tabular}{|c|r|r|c|}
\hline & G F R & E R P F & F F \\
\hline 1 & 78.2 & 355.0 & 0.22 \\
\hline 2 & 113.7 & 377.6 & 0.30 \\
\hline 3 & 71.3 & 244.0 & 0.29 \\
\hline 4 & 66.6 & 188.2 & 0.35 \\
\hline 5 & 85.5 & 274.0 & 0.30 \\
\hline 6 & 101.6 & 336.0 & 0.30 \\
\hline 平 均 & 86.1 & 295.8 & 0.293 \\
\hline Houck & $(84.4)$ & $(266.0)$ & $(0.317)$ \\
\hline
\end{tabular}

（）内は Houck が行つた正常犬75㖽の 「ク」值平均 
第 2 表

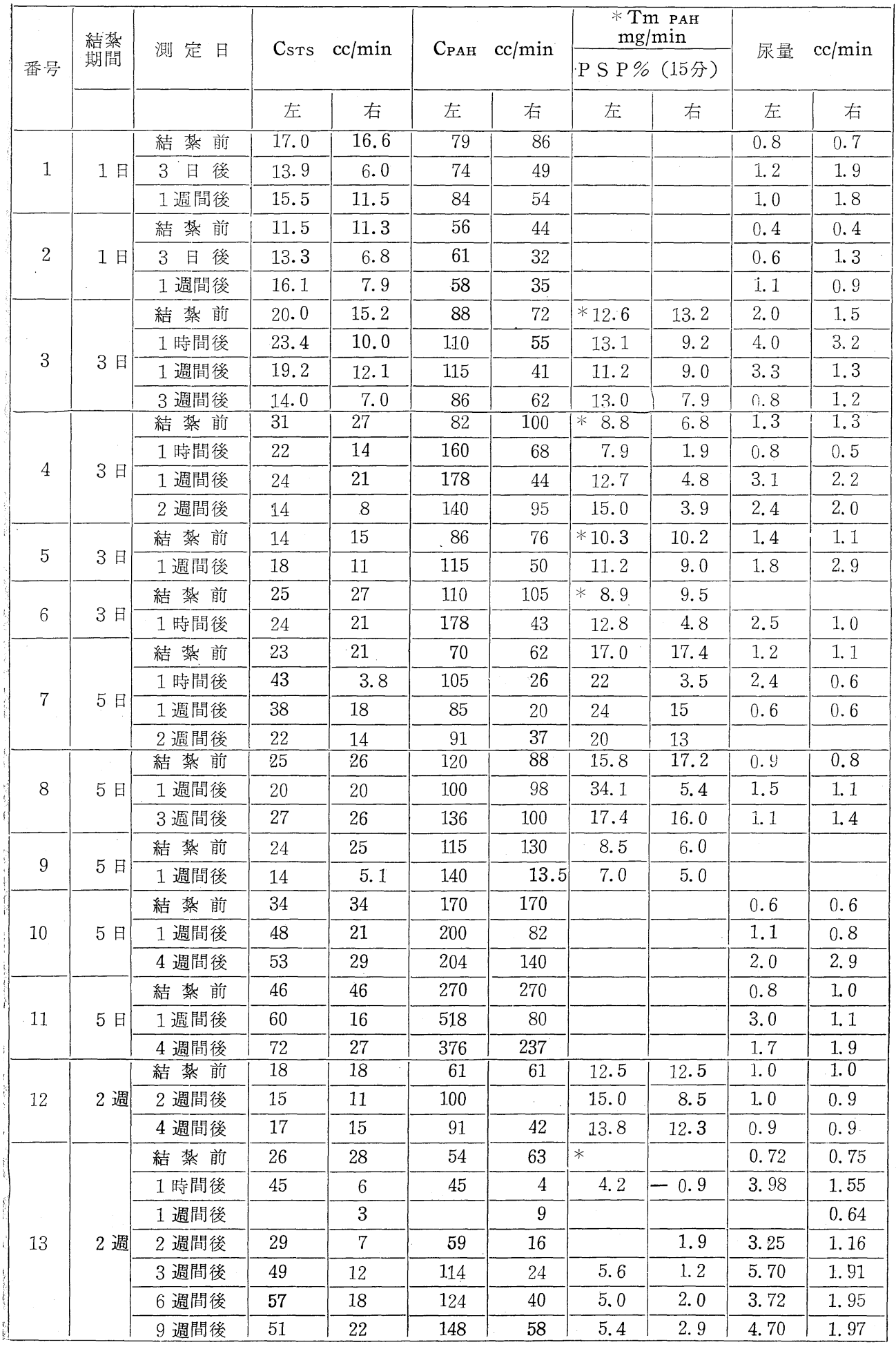




\begin{tabular}{|c|c|c|c|c|c|c|c|c|c|c|}
\hline \multirow{3}{*}{14} & \multirow{3}{*}{2 週 } & 結 禁 前 & 13 & 14 & 30 & 27 & $*$ & 2.2 & 0.27 & 0.27 \\
\hline & & 1 時間後 & 24 & 1. & 55 & 1 & 7.7 & 0.3 & 1.51 & 0.15 \\
\hline & & 1 週間後 & 19 & 3 & 48 & 5 & & & 0.22 & 0.08 \\
\hline \multirow{5}{*}{15} & \multirow{5}{*}{2 週 } & 結 禁前 & 29 & 26 & 56 & 65 & $* 5.4$ & 4.8 & & 1.91 \\
\hline & & 1 時間後 & 25 & 0.5 & 35 & 2 & 3.1 & 0.2 & & 0.17 \\
\hline & & 1 週間後 & & 0.3 & & 0.3 & & & & 0.03 \\
\hline & & 2 週間後 & 28 & 2 & 58 & 7 & 5.5 & 0.0 & 2.22 & 0.03 \\
\hline & & 6 週間後 & 40 & 2 & 80 & 2 & 4.0 & & 1.73 & 0.04 \\
\hline \multirow{3}{*}{16} & \multirow{3}{*}{2 週 } & 結 禁 前 & & 35 & & 89 & $*$ & 3.5 & & 1.47 \\
\hline & & I時間後 & & 20 & & 67 & & & & 1.52 \\
\hline & & 1 週間後 & & 4 & & 9 & & 0.6 & & 0.46 \\
\hline \multirow{5}{*}{17} & \multirow{5}{*}{ 3週 } & 結 禁 前 & 43 & 36 & 120 & 113 & $* 8.9$ & 6.9 & 1.51 & 1.20 \\
\hline & & 1 週間後 & 77 & 5 & 210 & 4 & 10.4 & 2.7 & 2.40 & 0.71 \\
\hline & & 3 週間後 & 85 & 13 & 165 & 28 & & & 4.35 & 1.51 \\
\hline & & 4 崌間後 & 97 & 14 & 230 & 32 & & 2.8 & 3.60 & 1.04 \\
\hline & & 7 週間後 & 74 & 13 & 165 & 33 & 9.8 & 2.4 & 4.55 & 1.39 \\
\hline \multirow{3}{*}{18} & \multirow{3}{*}{3 週 } & 結 禁 前 & 15 & 15 & 55 & 55 & 11.7 & 11.7 & 0.8 & 0.8 \\
\hline & & 1 時間後 & 23 & 7 & 73 & 18 & 15.0 & 2.0 & 1.0 & 0.73 \\
\hline & & 3 週間後 & 16 & 9 & 80 & 16 & 18.0 & 5.0 & 0.35 & 0.35 \\
\hline \multirow{3}{*}{19} & \multirow{3}{*}{3 週 } & 結 禁 前 & 21 & 18 & 54 & 46 & $* 6.2$ & 6.0 & 1.56 & 1.87 \\
\hline & & 1 週間後 & 28 & 6 & 75 & 5 & 6.7 & 2.0 & 1.63 & 0.65 \\
\hline & & 4 週間後 & 21 & 7 & 109 & 5 & & & 0.25 & 0.10 \\
\hline \multirow{3}{*}{20} & \multirow{3}{*}{3 週 } & 結 禁 前 & 35 & 33 & 118 & 100 & $* 7.5$ & 6.4 & 1.68 & 1.43 \\
\hline & & 1 時間後 & 27 & 4 & 140 & 8 & 12.3 & 0.4 & 1.32 & 0.38 \\
\hline & & 1挶間後 & 24 & 8 & 138 & 14 & 6.1 & 1.4 & 0.82 & 0.44 \\
\hline \multirow{3}{*}{21} & \multirow{3}{*}{3 週 } & 結 杽 前 & 22 & 22 & 71 & 71 & 12 & 12 & 0.9 & 0.9 \\
\hline & & 4.5週間後 & 34 & 14 & 96 & 50 & 11.9 & 8.1 & 2.0 & 1.9 \\
\hline & & 8 週間後 & 31 & 8 & 92 & 40 & 12.5 & 6.2 & 1.7 & 0.7 \\
\hline \multirow{3}{*}{22} & \multirow{3}{*}{ 3 週 } & 結 禁 前 & 26 & 26 & 77 & 77 & 17.0 & 17.0 & & \\
\hline & & 6 週間後 & 32 & 15 & 99 & 35 & 20.2 & 16.6 & & \\
\hline & & 8 週間後 & 43 & 12 & 113 & 35 & & & & \\
\hline \multirow{4}{*}{23} & \multirow{4}{*}{5 週 } & 結 禁前 & 13 & 13 & 69 & 69 & 15.0 & 15.0 & 0.65 & 0.65 \\
\hline & & 1 時間後 & & & & & 19.5 & 0.0 & & \\
\hline & & 2 週間後 & 15 & 7.3 & 93 & 38 & 13.0 & 7.0 & 0.5 & 0.5 \\
\hline & & 8 週間後 & 23 & 0.4 & 96 & 0.0 & 23.5 & 0.0 & 2.3 & 0.3 \\
\hline \multirow[b]{2}{*}{24} & & 結 禁 前 & 21 & 21 & & & 16.6 & 16.6 & & \\
\hline & 5 週 & 2 週間後 & 33 & 10 & & & 32.0 & 0.0 & 0.7 & 0.3 \\
\hline & & 結 禁 前 & 17 & 17 & 48 & 48 & 9.0 & 9.0 & & \\
\hline 25 & 5 週 & 2 週間後 & 31 & 3.3 & 84 & 6.5 & 18.0 & 0.2 & 3.7 & 0.33 \\
\hline & & 4 週間後 & 33 & 0.0 & 89 & 0.0 & 29.0 & 0.0 & 2.8 & 0.15 \\
\hline & & 結 禁 前 & 32 & 32 & 98 & 98 & 17.5 & 17.5 & 0.95 & 0.95 \\
\hline 26 & 5 週 & 5 週間後 & 60 & 0.0 & 255 & 0.0 & 26.0 & 0.0 & 0.2 . & 0.2 \\
\hline & & 結 禁 前 & 17 & 17 & 46 & 46 & 16.6 & 16.6 & 0.7 & 0.7 \\
\hline 27 & 8 迥 & 工時間後 & 33 & 0.0 & 91 & 0.0 & 32.0 & 0.0 & 3.1 & 0.2 \\
\hline 28 & 11调- & 結 禁 前 & 18 & 18 & 54 & 54 & 13.0 & 13.0 & 1.3 & 1.3 \\
\hline 28 & 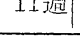 & 4 週間後 & 36 & 0.0 & 116 & 0.0 & 40.0 & 0.0 & 3.2 & 0.5 \\
\hline
\end{tabular}


計算は $\mathrm{Tm}$ PAH $=\mathrm{UV}-\mathrm{P} \times \mathrm{GFR} \times \mathrm{FW}$ で, $\mathrm{FW}$ は血漿 蛋白に結合し濾過されない $\mathrm{PAH}$ を差引いた補正值で, 大の場合は 0.92である. PAH の定量は Hamburger （1948）の方法に做い, 硫酸カドミウムで除蛋白後, Bratton-Marshall 反応で比色定量 (吉川) を行つた. STS の定量ほ Brun (1950)の方法で行つた。第1表 は 6 頭の対照健康成大のクリアランス值であり, 体表面 積 (B.S.A) $1 \mathrm{~m}^{2} て ゙$ 補正して表した。此の值は Houck （1948）の成績とよく一致していた。

体表面積快 Cowgill and Drabkin $\oslash$ 式

$$
\begin{aligned}
& \text { B.S.A }=\frac{2.268 \mathrm{~W}^{0.367} \times \mathrm{L}}{10,000} \\
& \mathrm{~W}=\text { 体重 }(\mathrm{g}) \\
& \mathrm{L}=\text { 鼻孔より肛門迄の長さ }(\mathrm{cm})
\end{aligned}
$$

で表される。

但し, 以後の本実験（第 2 表）では，同一動物で尿管 結紮解除後のクリアランス值を追求するのであるから, 補正の必要はないと考えすべて actual value で示し .

まず，下腹部正中切開により右尿管下端に達し（イ） 膀胱より $2 \sim 3 \mathrm{~cm}$ 上の部でこれを切断したのち右及び対 測 (膀胱尿による) 腎クリアランス值を測定した後, 右 漮管断端を二重結紮し，以後 1 週間隔で両側腎クリアラ ンス値昰測定した。

然し乍ら此の方法 (イ )では, 皮下の尿管結紮部が破 れて, 結禁解除前に尿瘦形成を来す例がかなりあつたた め(此等の不成功例埌䏛論放棄した) 後には (口) 膀脱 尿で結禁前のクリアランス值を測定し，二分した値を一 側腎の結紮前值とし，然る後右尿管下端を切断せずに二 重結禁して㧍き，一定期間後結紮上部で尿管を切断して 皮膚に移植した。

尿管結紮解除後の腎クリアランスは，右側は尿管皮膚 瘦方らの腎尿, 左側は膀胱尿で測定した.

本実験で，成績判定上最も問題となるのは，尿管皮層 移植口の狭窄発生己腎感染である，尿管皮膚移植口の狭 窄防止の方法としては，種及試久た結果第 1 区の如き尿 管皮膚移植衍 (Mc Donald-Heckel (1957) の変法) が 最もよい成績であつた。

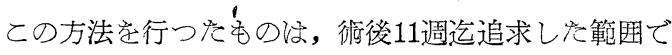
は狭窄は発生せず，ビニールカテーテル（尿管用）卭び No. 3 ネラトンカテーテルが常に容易腎㙉迄挿入可能 であつを（尚，初期の実験で，経過追求中尿管皮膚移植 口の狭窄が発生した実験例のデータは棄てた).
第 1 図尿管皮膚移植術式

(McDonald-Heckel の変法)
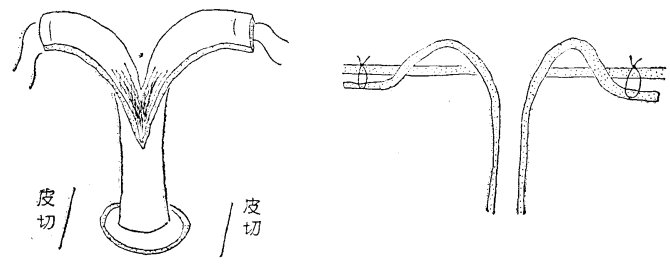

尿管を側腹部に出し，筋膜及び皮膚を狭窄予防 のため円板状に切除する。尿管を二分弁し，皮 切の部より皮下に埋没, 皮膚に固定し, 尿管口 㪕く皮膚に縫合する。

感染防止泣, 術前 Streptomycin 或は Penicillin の筋注及び Sulfa 成の経口投与を行つた。

一方, 犬の飼育状態も腎クリアランス值に可なり影響 があるょうであり，Kerr (1959) は，同一の大で, ク リアランス測定前及び測定中の食飼や給水の種々の組合 せにより GFRや ERPF は予想外に大きな変動学来すと とを報告している（同一大で GFR は 150〜 187\%, ERP F注 202〜 218\%にも及ぶ “ functional hypertrophy” を来すととがあるという).よつて筆者の実験でも出来る だけ大学一定の飼育及び測定条件にするょう心掛けた。

\section{実験成績}

以下の各図の (a)k於ては, 左右共に結紮前の警クリ アランス值を1.0己して, 結禁解除後の值を示した.

同一犬でも。日時学変えて測定すると, 腎クリアラン ス值は土20\%以内の差宗すととがあるため, 図 (a)に 於て結紮前值の $80 \%$ 以上飞達したものは，ほ济正常の腎 機能恢復したものと見做してょ亦ろう。

各図の（b)に於ては，結禁側（右）と対側（左）との 比を示した。尚, 対照健康大の結禁前值の左右腎クリア ランス值の比活。士20\%以内の差があつたととょり, 図

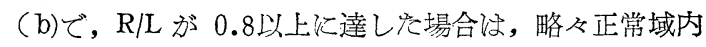
迄腎機能が恢復したものこ判断した。

(1) 一側尿管 1 日間結禁 ( 2 例)

結禁側の $\mathrm{C}_{\mathrm{PAH}}$ 况, 結禁解除後 3 日で, 結禁前値の57 〜 72\%，1 週後63〜80\%であつた.CSTsは，結禁解除後

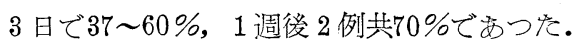

更に $2 \sim 3$ 週後にほ, 結紮前值迄㞍るであろうこと は, 次の3〜 5日の実験より推定してよかろう.

(2) 一側尿管 $3 \sim 5$ 日間結焚 (7 例)

(1) $\mathrm{C}_{\mathrm{PAH}}$ : 結禁側の $\mathrm{C}_{\mathrm{PAH}}$ 次，3〜5日間尿管結 紮解除後 1 週で30〜 110\%で 7 例の平均炡結禁前值の55 
第 2 図 a 一側尿管 3 5 日間結禁

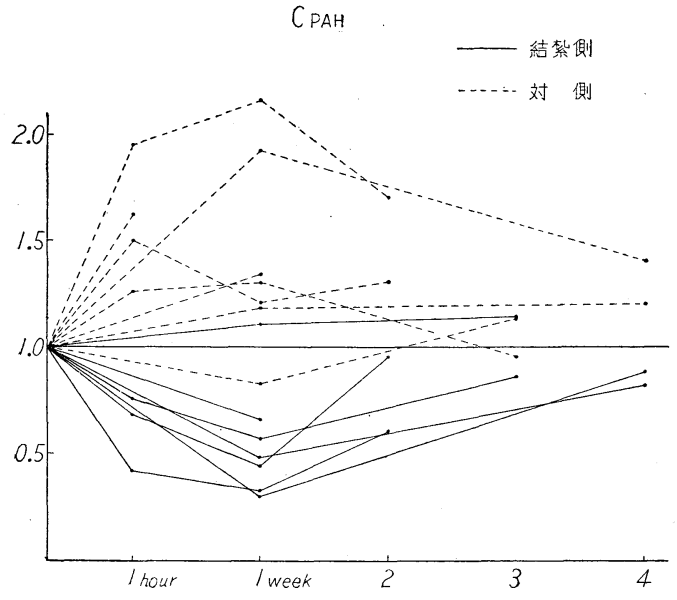

第 2 目 b

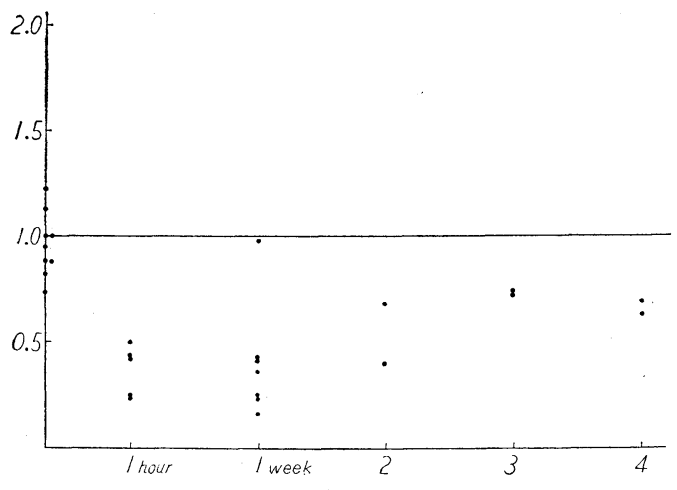

第 3 図 a 一側沓管 $3 \sim 5$ 日間結禁

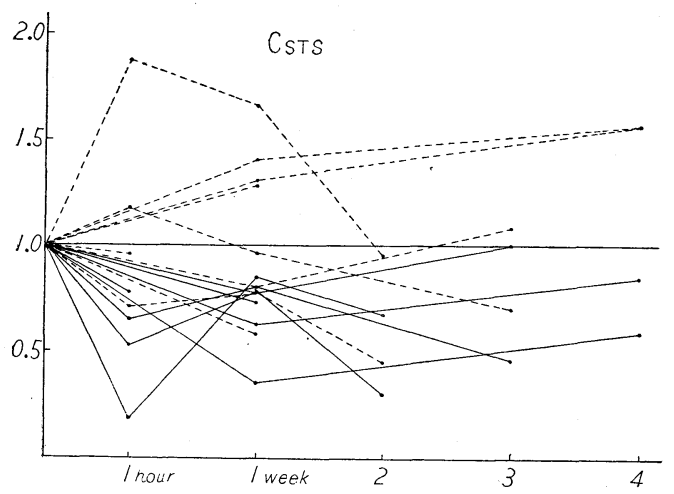

\%である.とのうち1例は既結紮前值を示して招り， 他の 6 例经結紮前值30 $56 \%$ で 6 例の平均 $46 \%$ あつ 在。
第 3 図 b

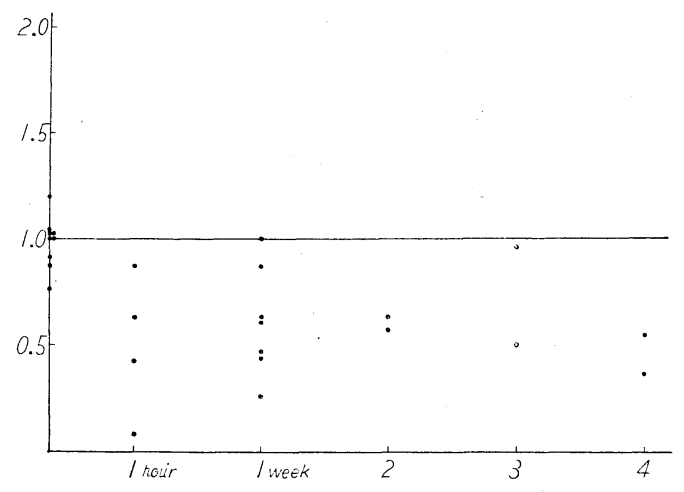

第 4 図 一側沓管 $3 \sim 5$ 日閒結禁

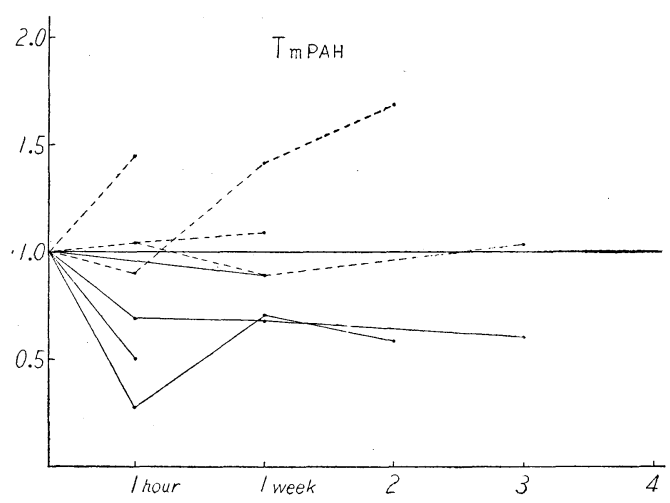

第 5 図一側尿管 $3 \sim 5$ 日閐絬禁 PSP

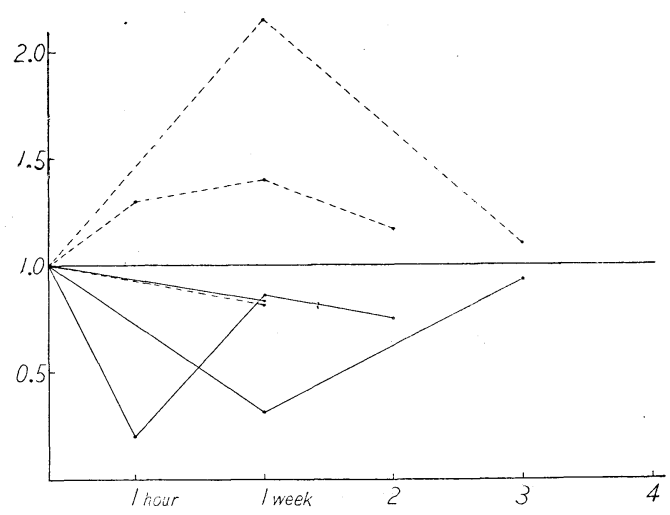

2 週後に恣, 2 例中 1 例註結禁前值に復し, 他の 1 例 は60\%であつな。

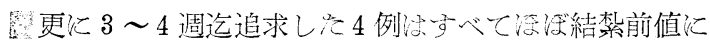


迄恢復していた. 即古, 解除倦 1 週では, 結紮前值の半 分の值に迄低下していたものが. 以後恢復に向い, $3 \sim$ 4 週で注全例略々結紮前值近く迄恢復した訳である.

対側腎の C PAH 以, 結紮側の推移に応じて代償性に機 能増加し, 両側腎の $\mathrm{C}_{\mathrm{PAH}}$ 合計怯, 結紮前己殆えご变り はなふつた。

次に，対側腎クリアランス值に対する結禁側值の比 R/L 定検討方る己，解除後 1 週で，7例中 1 例注略々結 紮前值と差がなき迄恢復し; 他の 6 例な16 43\%, 平 均 $30 \%$ ある。

解除後 2 週で注 $40 \sim 76 \%$ 平均 $53 \%$ となり, 更に $3 \sim 4$ 週で 4 例中 2 例 $280 \%$ 以上，他の 2 例活63 69\%で，5

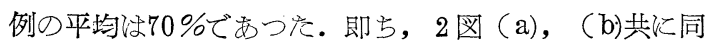
様の傾向を示し, $\mathrm{CPAH}_{\mathrm{PA}}$ 解除後 1 週以後恢復に 向い, $3 \sim 4$ 週では正常或は正常近く迄恢復していることが分 る.

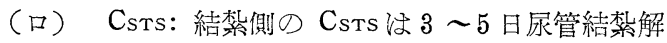
除後 1 週で $35 \sim 85 \%$ その平均值 $70 \%$ ( 7 例中 2 例々略々 結紮前值学示し，他の5 例は $35 \sim 78 \%$ で，乙の平均は65 \%) 以後の経過学みるこ 2 週（2例）では 1 週上り低下

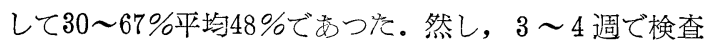
して他の 4 例では 46 ～100\%平均 $72 \%$ あつた. この 4

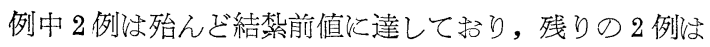
46〜 59\%平均 $53 \%$ あつつた。対側腎は, 結禁側の機能低 下に呼応して代償性機能増進を示すが, その傾向の著明 でない例もある。

次に, 対側腎クリアランス值との比R/L は，1週で7 例の平均は対側つ61\%( 552 例は対側と同等であり, 他の5 例《 $26 \sim 87 \%$ で平均 $54 \%$ ） 2 週で注 2 例平均 60 $\%, 3 \sim 4$ 週では 4 例の平均 $60 \%$ あつた（1例は対側 と殆んで差がなき迄に恢復し，他の 3 例嗵 37 ～55\%平均 47\%であつた).

(八) TmPAH: 3 5 日尿管結㛢解除後 1 週 (3 例) で，結禁前值の68 88\%平均 $75 \% ， 2 \sim 3$ 週 ( 2 例) で, 58〜 60\%平均59\%となつてい.

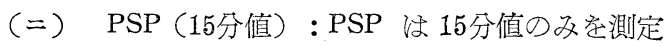
した. $3 \sim 5$ 日尿管結禁解除後 1 週で 3 例中 2 例は正常 域内で $2 \sim 3$ 週でほ 2 例共正常域内值学示した.

(3) 一側尿管 $2 \sim 3$ 週間結紮 (11例)

（イ） $\mathrm{C}_{\mathrm{PAH}}$ : 結禁側の $\mathrm{C}_{\mathrm{PAH}}$ 注解除後 1 週 (5 例) で $0 \sim 75 \%$ 平均 $19 \% ， 2$ 週（3例）で18 64\%平均 36 $\%, 3$ 週 ( 3 例) で25 38\%平均 $31 \% ， 4$ 週 ( 4 例) で 1 - 6 \% 耳均 $29 \%, 6$ 週（3 例）で $3 \sim 63 \%$ 平均 $37 \%$,
8〜 9 週（3例）で45〜93\%平均65\%であつた。

その経過をよく追求出来た 3 例についてみると，2 例 法解除後 1 週より 4 〜 週迄殆んで改善傾向がなかった (との 2 例は共に $10 \%$ 程度の值で 1 週以後追求した 4 6 週迄固定している). 然し他の1例梳 1 週以後徐々に 改善されて行き，最初の1週で14\%に過ぎなかつたもの が，2週で25\%，3週で38\%，6週で63\%，9週では遂 に93\%己結禁前の正常域内值迄恢復していたととが注目 される。

次に対䇾との比 $\mathrm{R} / \mathrm{L}$ そ，2週で1例の及対側 $\mathrm{C}_{\mathrm{PAH}}$ に 匹敵する例があつ它が，他注 2 週以後 9 週宗での範囲で 対側の40〜50\%止りであつた。

(ㅁ) Csts: 結禁側の CsTs 恰解除後 1 週 ( 8 例) で 1 57\%平均 $18 \% ， 2$ 週（3例）で 7 61\%平均 31 $\%, 3$ 週 ( 3 例) で37 60\%平均 $46 \%, 4$ 週 ( 3 例) で 11 $83 \%$ 平均 $44 \% ， 6$ 週（ 3 例）で $7 \sim 64 \%$ 平均 $43 \%$ ，

$8 \sim 9$ 週で38〜 $80 \%$ 平均 $53 \%$ \%であつた.

経過を追つてよく追求出来た 3 例仙いてみると, 2 例法解除後 1 週以後 6 〜 週迄明示な改善傾向は2られ なふつた（この 2 例中 1 例は 1 週後 $4 \% て ゙ ， 2$ 週より 6 週迄 $7 \sim 8 \%$ に固定し，他の1例も 7 週迄凡气 $35 \sim 40 \%$ に固定している).

1 例は 1 週以後徐கではあるが進行性に改善されてい き，1週では10\%に過ぎなかつたのが，2週で $24 \% ， 3$ 週で35\%，6週で64\%，9 週では遂に80\%と略々結禁前 值の下限に達している。

対側腎乞の比 R/L は，4 週で対側腎に匹敵する值に

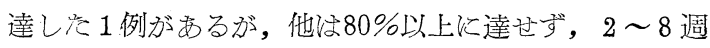
の間で50\%以上に達したものは 2 週で 4 例中 2 例， 3 週 で 3 例中 2 例, 4 週で 3 例中 1 例, 5 週以後活 7 例中 1 例もなかつた。総じて, $1 \sim 8$ 调の間大部分の例は, 対 側の約 $20 \%$ に過ざなかつた。

（八） T TPAH：2 3 週間尿管結紮解除後 1 週 (4

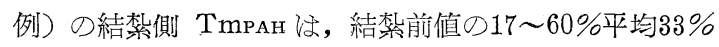
であつた。この7例のうち，1週後60\%であつた1例は 解除後 3 週及び 7 週後にば結紮前值迄恢復していた。

他の 1 例は 2 週で40\%，3 週で24\%，9週では50\%の 值走してい宗。

R/L 㳊解除後 1 週より 8 週の間, 対側腎 TMPAH の20 〜 40\%の範囲内にあり、9 週で1例は対側腎の54\%であ つ\%.

（二 PSP: $2 \sim 3$ 週間尿管結紮解除後 $2 \sim 3$ 週 ( 2 
第 6 目 a 一側尿管 $2 \sim 3$ 週結禁

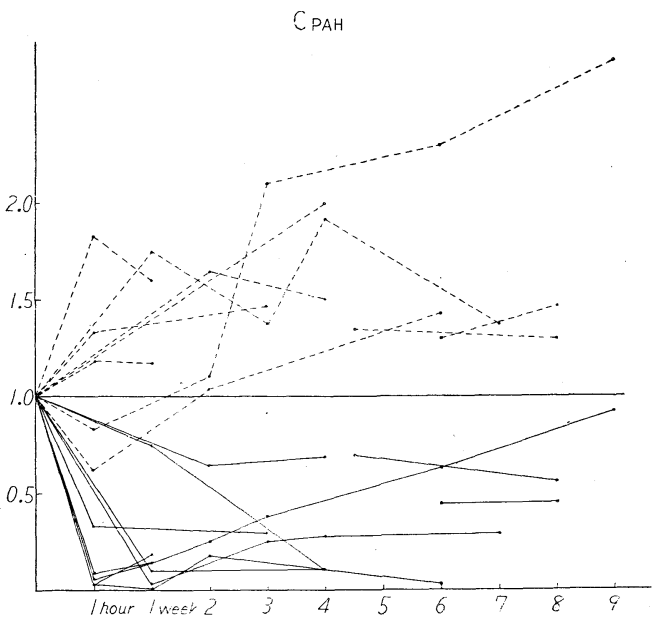

第 6 図 b

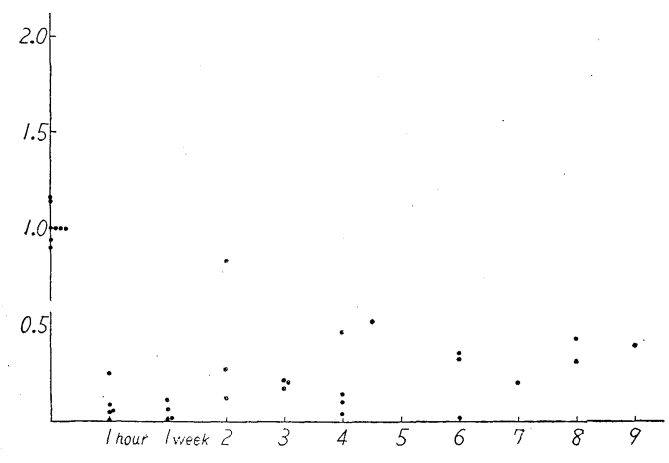

第 7 図 a 一側求管 $2 \sim 3$ 週間結禁 Csts

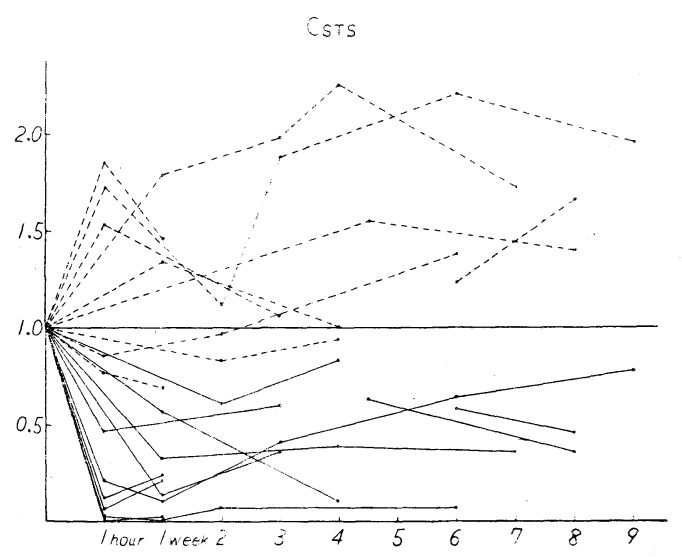

第 7 沾

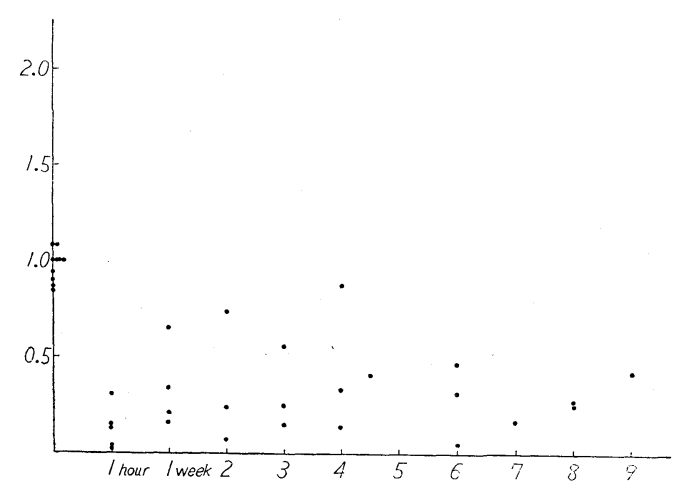

第 8 図 一側尿管 $2 \sim 3$ 週結禁 TMPAH

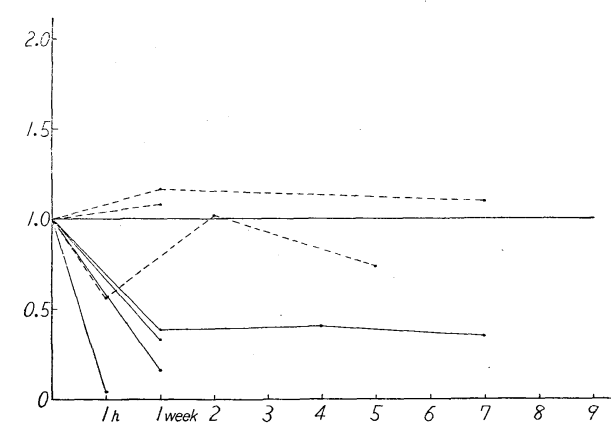

第 9 図一側尿管 $2 \sim 3$ 週結禁 P S P

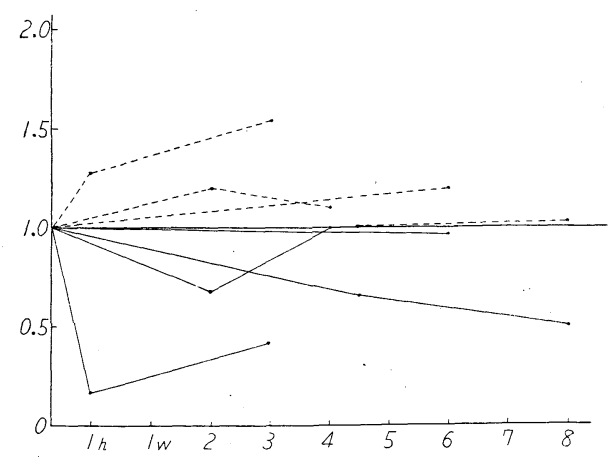

例)で，結禁側洁結禁前値の 43〜68\%を示すが， 4 〜 週後 ( 2 例) では正常值に復していた（但し， 8 週後結 禁前值の $50 \%$ 宗した 1 例があつた).

（4）一側尿管 5 週間結㛢 (4 例) 第10～第12困 5 週以上結禁例では, 解除後尿量は極めて少量で, ク リアランス測定不能の犬も時にあつたが，乙れ等はすべ 


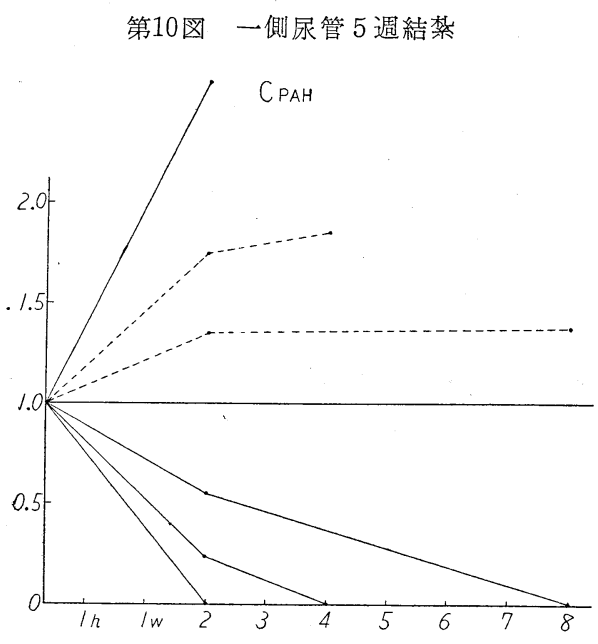

第11図 一側尿管 5 週結禁

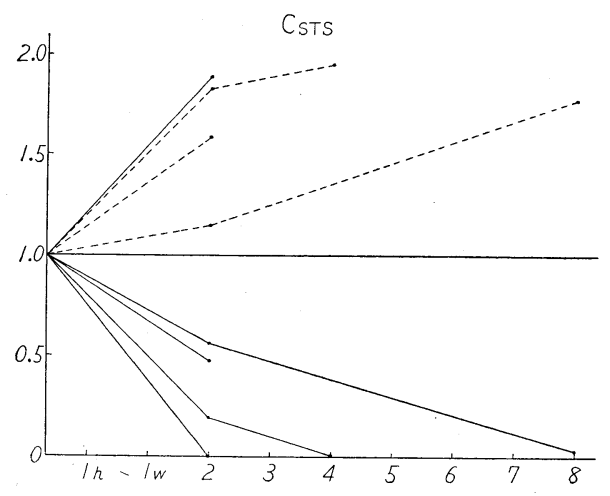

第12図 一側尿管 5 週結禁

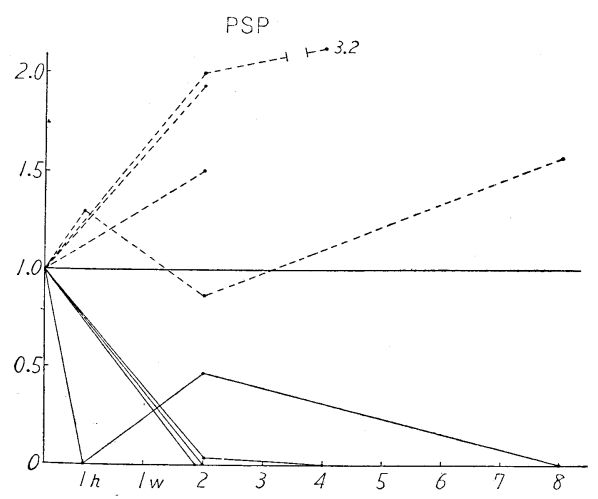

て放棄した。

クリアランス值を測定追求した大はすべて, 規定の補 液後尿量が $0.2 \mathrm{cc} / \mathrm{min}$ 以上のものであつた。
(イ) $\mathrm{C}_{\mathrm{PAH}}$ : ( 3 例)

$\mathrm{CPAH}_{\mathrm{PA}}$ は解除後 2 週 ( 2 例) で結紮前值の 14 54\%平 均 $34 \%$ あつた. 然るに $4 \sim 9$ 週後に㵔しく機能低下 し零もしくは殆んざ零に近くなつていた. 他に解除後 9 週で $\mathrm{C}_{\mathrm{PAH}}$ が零の1例があつた。

(口) Csts: (4例)

CsTs は解除後 2 週 ( 4 例) で結禁前値の 20〜 $56 \%$ 平 均 $41 \%$ であた. 此のうち2週で20\%示した 1 例は 4 週後には零となつた。同じく 2 週で56\%であつた 1 例 は， 8 週では $3 \%$ \%つていた（残りの 1 例は 2 週で48 \%学示したが以後の追求学していない).

其の他結禁解除後 9 週で CSTS 雺を示した 1 例があつ た.

(八) PSP: ( 4 例)

PSP は解除後 2 週 ( 2 例) で結禁前值の $2 \sim 46 \%$ 平

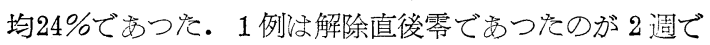
46\%己なり， 8 週では零さなつた。1例は 2 週で $2 \%$, 4 週で零上なつた. 他の 2 例は解除後それぞれ 2 週, 9 週で零の值を示していた。

即ち, 此の結㛢群では $\mathrm{CPAH}_{\mathrm{PAH}}, \mathrm{C}_{\mathrm{STS}}$, PSP 共に略々同 一の傾向が認められた。 即ち, 解除後 2 週で, 結紮側腎 は三測定值共に低值ではあるが，かなりの值字示してい たが, 3 週以後の測定值は何れも零もしくは零に近い值 であつた。

な扮, 本実験に関連して行つた 2,3 小実験成績を 下記列記する。

a) 尿 $\mathrm{pH}$ とンモニア 第13図

$3 \sim 5$ 日間尿管結禁解除後の尿 $\mathrm{pH}$ とアンモニア排泄量 との関連は第14図の如く, 結紮側は解除後一般に尿はア ルカリ側に傾き，アンモニア排泄量は比較的に低下して いる傾向が認められた. これ等の值已結禁解除後の日数 この間に一定の関係学認めなかつたので，一括して第13 図に示した。

b) 酸塩基負荷試験 第14図

一側尿管 5 日間結紮し, 解除後 3 週で略々正常に近く 腎機能が恢復した例に於て, Leberman 氏法による酸塩 基負荷試験学行つた結果第15図の如く, 結㛢側腎の酸塩 基分泌能も対側に比して幾分劣つているようではある が、略々正常範囲内にあつた。

c) 3 日間尿管結禁群, 及び 3 週間尿管結禁の各 1 例 （第 2 表のNo. 8 及び No. 22）に於て, 結紮解除後略々

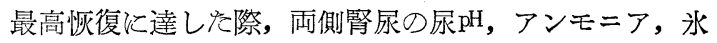
点降下を測定した (第 3 表). 尿量は左右略々等しく, 結 
第13図 一側尿管 $3 \sim 5$ 日結紮解除後 の尿 $\mathrm{pH}$ とンモニアの関係

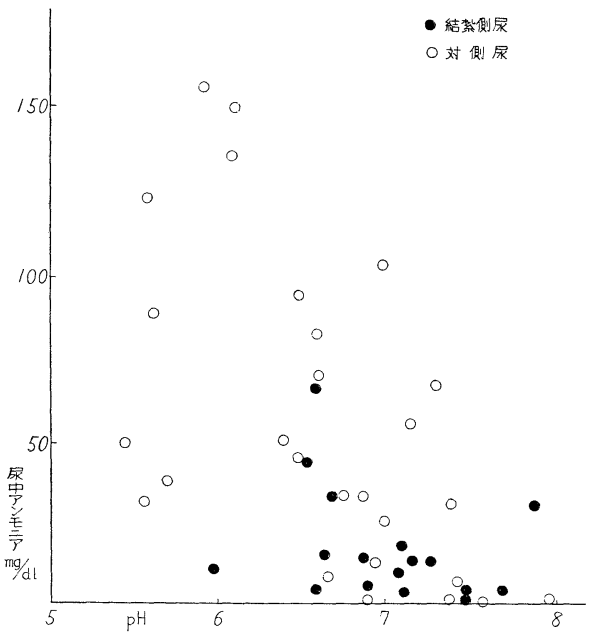

第14図 酸塩基負荷試験（Leberman 氏法）

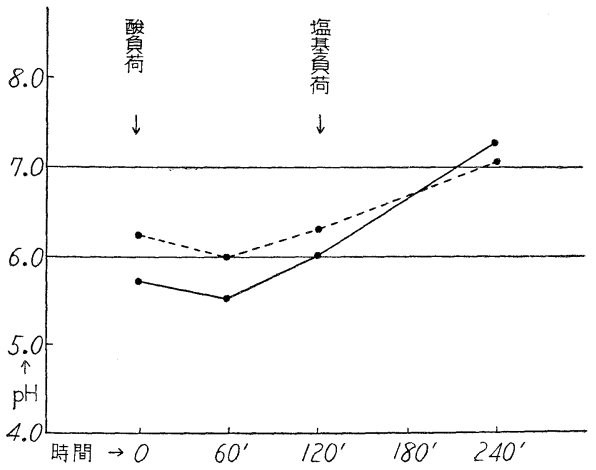

紮側の尿外観は対側に比して色調は稀薄であつた。 3 日 結椤側では両腎共に, $\mathrm{pH}$, アンモニア，氷点降下注左右
近似し差がみられなふつた。3週結紮例では, pH，アン モニアは左右差はなふつたが, 氷点降下は結禁側が対側 に比して低值であつた。

d) 静脈性腎需撮影像 第15困

3 週間尿管結紮例（第 2 表No. 21, No. 22) で, 解除 後30日〜 6 週に於て静脈性腎孟撮影导行つた（此の時の 腎クリアランス值は， $\mathrm{C}_{\mathrm{PAH}}$ は70\%及び $45 \%$, C $\mathrm{STS}$ は $63 \%$ 及び57\%の恢復值であつた） 2 例共造影用排泄能は 良好である（No. 21に行つた逆行性腎孟撮影による腎㙉 形態は中等度の拡張を認めた).

即ち, 腎孟撮影で造影剂排泄機能が良好でも, 腎の GFR, RPF㳊可なり低下しているここがある.

対側腎盂像が認めら扎ないのは, 造影郕が既に膀胱に 排泄されたためである。

一側尿管 5 日間結紮解除後 3 週で, Csts, C

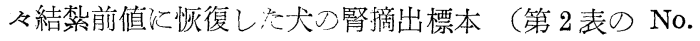
3）经第18図の如く，中等度の腎内腎盖の拡張乞，腎実 質の軽度の萎縮がみられるが，尿管の拡張は全くみられ ず，尿管移植口の狭窄もな少つた。

組織学的所見は，壁島及び Kerr の記述と大差なふ つ.

e）水再吸收率 第17図

一側尿管 $2 \sim 3$ 週結紮例の, 解除後の水再吸収率定計 算すると第17図の如く, 結㛢解除後 1 時間では極めて低 值定示しているが, 解除後時日の経過亡共に上昇して行 き, 数週後には結禁前值に近い所迄㞍つてくる例もあ る.

\section{文献的考察}

腎盂内压上昇によつて起る一連の変化については古来 多数の研究がある. 年ず, 実験的に尿管を完全に結禁す るこ腎需内压上昇が起るが, この際, 腎は一次的萎縮に

第 3 表 尿管結禁解除後機能恢復時の尿所見

a) 一側尿管 5 日結禁解除後 3 崌の尿所見

（第 2 表の No. 8)

\begin{tabular}{|c|c|c|c|c|c|c|c|}
\hline & Csts & $\mathrm{C}_{\mathrm{PAH}}$ & $\begin{array}{l}\mathrm{PSS} P \\
\left(15^{\prime}\right)\end{array}$ & 尿 $\Delta \mathrm{t}$ & 尿 $\mathrm{pH}$ & 尿 $\mathrm{NH}_{3}$ & 尿 \\
\hline 結禁解除例 & 26 & 100 & 16.0 & 0.19 & 6.6 & $7.0 \mathrm{mg} / \mathrm{dl}$ & $1.4 \mathrm{cc} / \mathrm{min}$ \\
\hline 対 & 27 & 136 & 17.4 & 0.20 & 6.9 & 70 & 1.1 \\
\hline
\end{tabular}

b) 一側尿管 3 崌結禁解除前後 6 崌の尿所見

（第 2 表の No. 22）

\begin{tabular}{|l|c|c|c|c|c|c|c|}
\hline & CSTS & $\mathrm{C}_{\mathrm{PAH}}$ & $\begin{array}{c}\mathrm{P} \mathrm{S} \mathrm{P} \\
\left(15^{\prime}\right)\end{array}$ & 尿 $\Delta \mathrm{t}$ & 尿 $\mathrm{pH}$ & 尿 $\mathrm{NH}_{3}$ & 尿 \\
\hline 結禁解除例 & 15 & 35 & 16.6 & 0.6 & 7.0 & 3.4 & \\
\hline 対 & 32 & 99 & 20.2 & 1.6 & 7.0 & 3.4 & \\
\hline
\end{tabular}


陥つて了らこと济さしろ稀で, 尿分泌排泄機能忟（勿論 減退はしているが）可なり長期亘つて存続している.

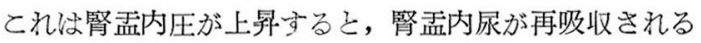
そいう特殊な機構があるためである。此の再吸収の経路 怯, Hinman 一派, Fuchs (色素), Narth (造影郕) 以後最近の Goodwin, Persky（放射性同位元素）迄多 くの研究がある. 細郆就いてはな扮論議もあるが, 要 するに腎孟内圧上昇時镸も抵抗が弱い腎杯円蓋部の粘膜

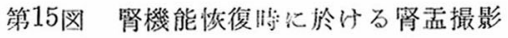
1. a 第 2 表 No. 21 の I.P.

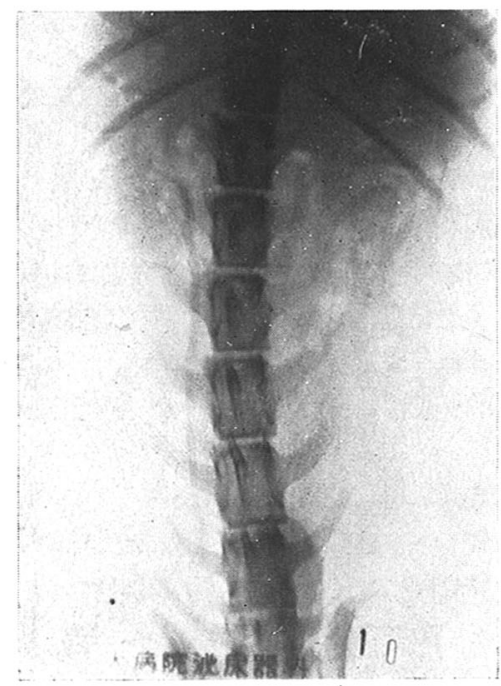

1. b a の R.P.

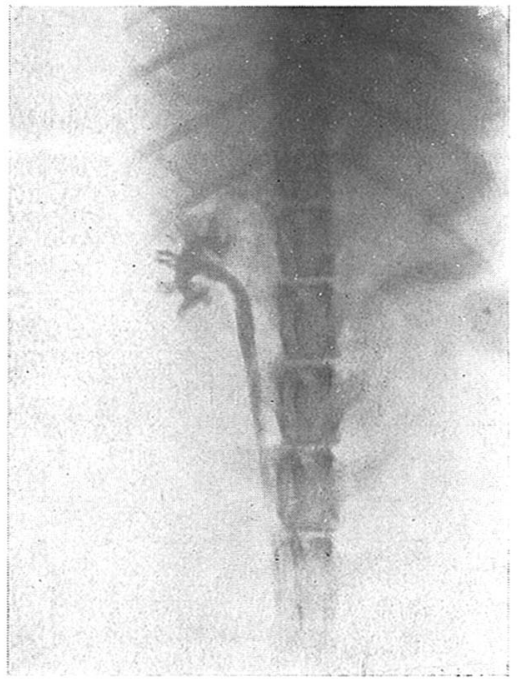

2. 第 2 表 No. $22 \%$ I.P

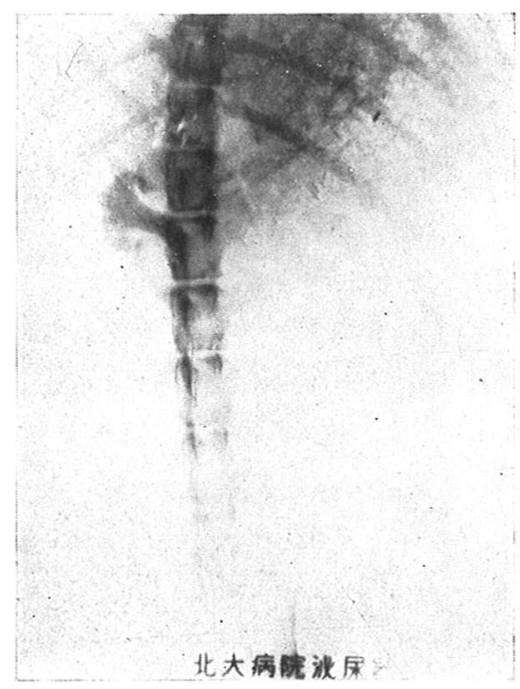

に微細な隙間が出来て，これより粘膜下に進入した尿が 静脈内に逆流 (Pyelo-venous backflow) 或惊腎洞淋巴 系により運搬される (Pyelo-sinus transflow). 又内圧 上昇により集合管よりネフロン内に逆流した 尿が尿細 管周囲毛細管や淋巴管内に入り乙光 (Pyelo-canalicular backflow) というのである.

Harrow（1954）は臨床的に造影剑が腎盂壁及び尿管 上部より吸収さ沉る事学報告しており，私は大の尿管下

第16図 1 側尿管 3 日結奖解除後 機能恢復時の腎尿管摘出標本

（第 2 表 No. 3)

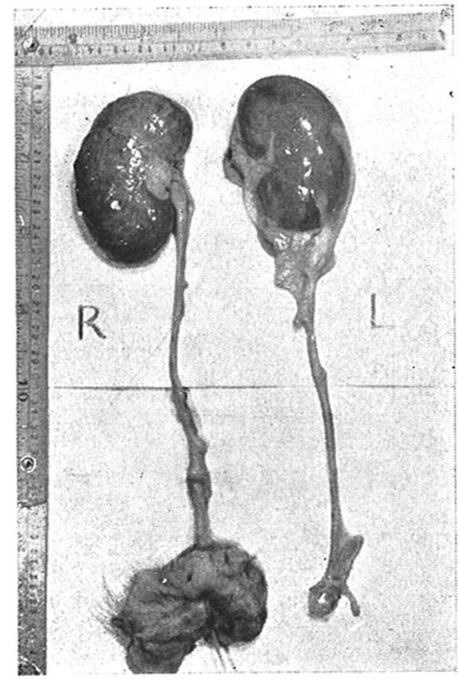




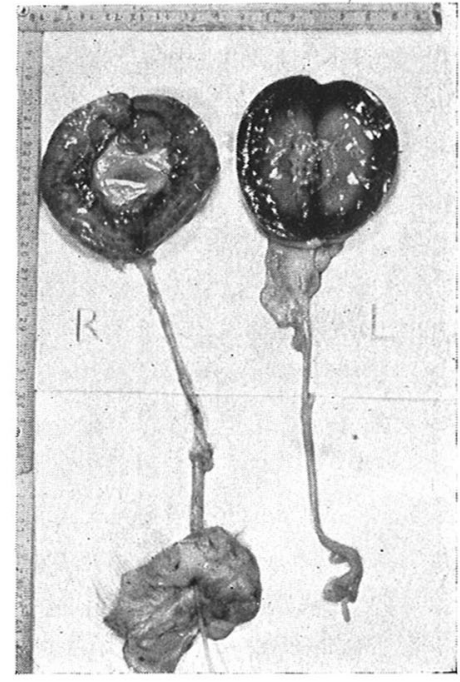

第17図 一側尿管 $2 \sim 3$ 週結紮解除後 結奖側の水再吸収率

$\frac{G F R-V}{G F R} \quad V: 1$ 分間の尿量 $c c$

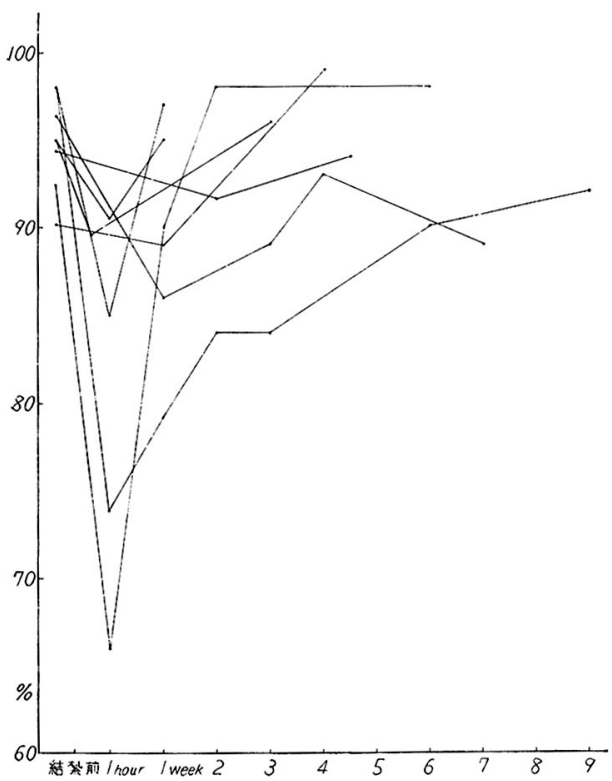

部結紫の際尿管内に色素注入学行い，3 日後剖検的比尿 管壁外への色素の著明な溢出定認めた。

一般に外分泌腺でば排泄管を完全に開塞すると直ちに 内压が分泌圧以上に上昇するために腺の分泌活動が停止 して了うととが多いのであるが，腎ではとのような腎衁 尿再吸収という安全弁によつて, 無制限の内压上昇が防
止されているために尿分泌機能を可なり長期に亘り保有 していると説明される. 微点をふえれば, 水腎は尿の生 成分泌之腎瑥尿の膀胱への落下及び再吸収との不均衡に よつて進行するる云えるすけである。

な扮, 腎盂内圧上昇時の糸球体及び尿細管機能に就い ては橋本, Sharre, Selkurt, 渡井等の論交がある。

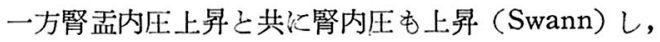
腎盖及び腎内圧上昇訬腎血流障害を来卞, 腎盖内压上昇 と拡張に心り䇾葉間動脈以下の動脈枝は圧迫 - 延長 - 狭 化され，特心，尿細管周囲血管は血流停滞し(Hinman), 腎静脈系も同様な変形と血流停滞を来し（Ferrer）, 腎 血流量减少してくる (Lucas, Maatz, Levy, Idbohrn, Sharre, Selkurt, 渡井等).

尿管狭窄が一定期間以上に亘れば, 斯る血流障害によ つて当然腎実質変性萎縮が 招来される. Hinman 及び Hepler は，尿管結紮己共に腎動脈の部分的閉塞を行う 之腎萎縮が著明に促進される実験ふら，実質障菁の主因

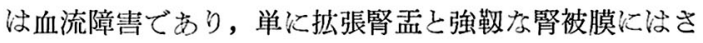
まれたためでないとと少証明している。

さて, 私の主題である尿管通過障得除去後の腎・上部 尿路の形態機能の恢復についても古来幾多の研究があ る.

Rautenberg (1906), Rötzel (1914), Johnson (1918), Joelson (1929), Hinman (1945) 及びその一派等であ り, 本邦では川添 (1930), 壁島 (1928), 藤倉 (1933), 富 永 (1930), 橋本 (1943) 等である.

何えす, 実験動物としてラッテ, 家鬼或は犬を用い一 側尿管結紮解除後尿路変更をなし（尿路变更及び移植部 の狭窄, 感染に関する詳細な記述は少ないが), 時間学 追つて, 腎, 尿管の病理組織学的或は機能的 (尿量・尿 成分・色素排泄能等) 検查を行つている.

一側尿管の短期間結枈実験としては橋本の詳細な実験 がある。

彼は犬を用い, ごく短期間（ 5 〜 時間）尿管を完全 結紮し, 解除後カテーテルを尿管内に挿入し, 尿量及び 各種尿成分党測定している。

尿量は解除後増量し, 20 特間後も対側の 2 倍量学保 ち, 結紮側の炭酸塩, 塩酸塩の著しい排泄増加及び塩酸 塩, $\mathrm{Na}$ の軽度の増加をみ, $\mathrm{K}$, 馬尿酸. クレアチニン は著変なく， 尿は対側に比してアルカリ側に傾くと云 3.

色素排泄能としては, カルミンは殆んど不変, フェノ 
ールロート，中性紅は軽度の排泄低下をみたと述べてい る.

次いで, 長期間の尿管結紮実験としては, 同じく本邦 の壁島の実験がある.

壁島は家鬼を用い, 一側尿管 1 35日間結紮し, 解除 後最長 11 日間追求し, 尿中の尿素, $\mathrm{NaCl}$ 及び PSP 等 で腎機能の追求を行い, 併せて組織学的な恢復機序を検 討している.

壁島の実験による己，1～5 日間結紮 (初期) 及び 6 〜12日間結焚（多尿期）では，結禁解除後 1 日で, 糸球 体及び特に尿細管の障害を認め, 色素排泄能及び PSP の減少, 及び $\mathrm{NaCl}$ 排泄量・尿量等の増加があるが, 解除後 $2 \sim 6$ 日では殆んぞ恢復し, 左右腎の諸機能及び 組織学的所見は全く同等となつた。

結禁期間13〜17日（移行期）では、解除後10日で軽度 恢復傾向学認めるのみで, 組織学的には近位尿細管より 下の部分の変性が明永であつたという。

結禁期間18～35日（乏尿期）では，解除後では，解除 後11日迄追求した範囲で, 組織学的機能的に高度の障害 を有し，恢復傾向は認められなかつをと記載している。

Hinman 及びその一派は, 家鬼及び犬による動物実験更 に臨床成績そ, 過去の多数の学者の実験成績学総覧し有 名な renal counterbalance 説学提唱した.との言葉は総 腎機能に於ける両側腎の分担定定義するものであつて， 一側尿管通過障害により, その側の腎障害が起ると, 対 側腎注代償性肥大, 機能克進を来卞。

水腎が一定以上に進行すると，たとえ通過障害を除去 することにより多少の機能が恢復しても，既に肥大した 対側腎が代謝老廃物学殆んぞ総て排泄して了うので，障 害腎は使用されないで，一定期間後に萎縮して了う。

即ち，一定以上飞障害された腎（総腎機能の $1 / 5$ しふ 分担して扔らず，単独では生命維持不可能の腎) 坟対側 肥大輎と競う能力を失つているこいうのである.

尔た, Hinman の実験によると，一側尿管結禁60日以 内であれば, 結禁日数之, 恢復傾向との間に相関関係が 見出され，1〜2週間以内の結禁であれ極めて良好な 恢復を期待しろるという. 和を, 一側尿管 $1 \sim 2$ 週間の 結紮解除後, 対側腎学摘出した場合, 結禁側腎は 40 日後 及び 152 日後代償性肥大と, 略々充分な機能に恢復した という.

即ち, 通過障害除去後, 対側腎学剔出して了うと, 進 行した水腎も必要に迫られて, 再び可なりの機能を恢復 するという説である・最近の Kerr や，渡井等の尿管結
紮解除後の腎クリアランスの研究でもとの説を裏付ける 成績であり, 確かにこのような傾向は存在している。然 し一方, 可なり進行した一側水腎症も, 通過障害除去後 （対側腎の代償性機能肥大《拘らず）著明な機能形態の 恢復安示すととが, 臨床的に曹及経験されており, Hinman 等の如く, 仂く必要がない方ら萎縮して了うとい うのは多少行き過ぎであろう. Joelson は, 大の 1 側尿 管11 19日間結禁し, 解除後最長 807 日追求した結果, 結禁側腎は常に対側腎との競合能力安保持しているとい い Hinman の説に反対している.

最近 Holder 注大の一側尿管にラミナリア学挿入 2 カ 月以上の閉塞で, 高度の水腎に到達したものも, ラミナ リア除去後に注, 不完全狭窄は $5 \sim 6$ 週で, 完全狭窄で も25週位で, 略々正常機能, 形態に復帰したという.

臨床例の尿管結禁解除後の腎機能恢復については Harrow の文献的考察がある.

St. Martin 19 日, Day は23日間の一側尿管完全狭 窄例で, 狭窄除去後の腎機能恢復を認めて扣り, 本邦で も, 梄原, 大越, 岡等の居様な報告がある.

尿管結椟解除後の腎機能の恢復状態孝, 新しい検查法 である腎「ク」を用いて追求したのは交献的に, Kerr (1954，1956）が最初のようである. Kerr 注雌成大の 1 側尿管を $1 \sim 4$ 週間結紮し, 結紮解除・尿管皮膚移植 後の腎クリアランス (Cin, $\mathrm{C}_{\mathrm{PAH}}$ ) を 1 週間隔で追求し ている、それによると 1 側尿管 1 週間結禁 (10例) で

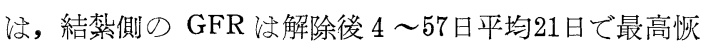
復值60〜 74\%平均 $68 \%$ 亿達した。等決, 結紮側の $\mathrm{ERPF}$ は解除後 $4 \sim 57$ 日平均 21 日で最高恢復值 55 ～ $66 \%$ 平均 66 \%に達して。なお, 対側腎 GFR, ERPFは代償性㐳元進 し結紮前值の $130 \%$ に達した。

一側尿管 2 ・ 3 週間及び 4 週間結紮注各 1 例ずつであ るが，2週結禁では GFR, ERPF は2 週後24〜29\%, 3 週後33〜37\%であり，62日後39〜 42\%に達した（対側 腎「ク」值は 130〜 155\%).

一側尿管 3 週間結禁の 1 例注解除後 28 日で恢復值GFR 前值の $37 \%, \mathrm{ERPF}$ 前值の $35 \%$ に達していた（対側 GFR, ERPF 前值の 127 109\%). また， 4 週間結禁

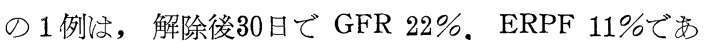
$つ た$.

当敉室の先輩渡井 (1957) は, Kerr 同様に大の 1 側 尿管 $1 \sim 4$ 週間結紮解除後の腎機能を, Csts, $\mathrm{CPAH}_{\mathrm{PAH}}$ TMPAH より追求している.

これによると，1側尿管 1 週間結紮（2 例）では結紮 
測の GFR 注解除後 1 時間で結禁側值の72〜105\%さい 弓案外良い值定したが, 3 日後, 1 週間後已徐々に減 少し, 結皆前值の $28 \sim 45 \%$ 迄下り, 2 週後も略及同値を 示し, $\mathrm{ERPF}$ む殆んで同様の経過であつた。

結禁側の TmPAH 注解除後 1 週, 2 週共に対側腎の38 〜 47\%宗した。

然し 2 週結禁の成績より各「ク」值共に 2 週以後更に 恢復するであるうこ推定している.

1 側尿管 2 週間結禁でほ，結禁側の GFR は解除後 1 週で 1 21\%平均 $11 \%$ あつたが，2週後方ら徐々に恢 復定示し 9 週後に注79\%に達した 1 例があつた。 この例 の ERPF 证更に恢復がよく, 9 週で95\%に達してい た.

1 側尿管 3 週及び 4 週間結禁では, 解除後 $1 \sim 2$ 週で GFR は 6 33\%, ERPF は 4 〜14\%であつたが, 3〜 7 週後で浪, GFR, ERPF 共に殆んざ恢復傾向を示して いなかつた。

\section{自家成績概要}

私の実験によると，一側尿管 1 日間結禁 ( 2 例) で 注, 結禁側の ERPF 注結禁解除後 3 日で結紮前值の平 均 $65 \%$, 1 週で71\%である. GFR は解除後 3 日で結梦 前值の平蚐 $64 \%, 1$ 週で70\% 己良好な成績を示してお る.とれらより，1日結禁では ERPF, GFR 共飞解除 後速や办腎「ク」值が正常近く迄恢復することが分つ

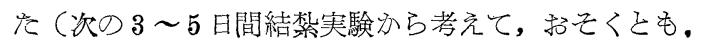
4 週以内に全〉正常に復するものと判断出来る).

一側尿管 3〜 5 日間結紮 ( 9 例) では, ERPF 結 椟解除後 $3 \sim 4$ 週迄追求した 4 例全部が結紮前值に恢復 していた（な掠 1 〜週で既に結枈前值に恢復した例も あつた).

GFR も結禁解除後 $3 \sim 4$ 週迄追求した 4 例中 2 例は, 結紮前值に恢復していた. 他の 2 例注前值の平均 $53 \%$ で あつた。

TMPAH ほ結紮解除後 $2 \sim 3$ 週で, 追求した 2 例は結 禁前值の $58 \sim 60 \%$ 平均 $59 \%$ であつた。

PSP洁結紮解除後 1 週で 3 例中 2 例, 友び, $2 \sim 3$ 週 で 2 例中 1 例, 結禁前值に恢復していた。即ち, $3 \sim 5$ 日間尿管結紮では, 結紮解除後 4 週で腎機能は何れも略 々正常迄恢復可能な事が明かとなつた。

一側尿管 $2 \sim 3$ 週間結禁で淰, 解除後 1 週の $\mathrm{CPAH}_{\mathrm{PAH}}$ は, 平均 $19 \%$ ある. 以後 6 週迄殆んご改善㑯向をみぬ ものと，1週以後漸進的に機能改善する群に分かつこと
が出来る.

1 週以後改善傾向の及られな加をものは，尿管皮膚 移植口の狭窄が発生したり, 腎感染学来たしたものであ つた。狭窄も感染もなかつたものは，一般に解除後の CPAH值恢復が良好で且つ時上共に更に改善されておる。 1 例既に 2 週以後 $64 \%$ 值定示して沶り, 又小く追求出 来な他の 1 例では，最初の 1 週後 $14 \%$ に過ぎなかつたも のが，以後直線的に恢復し，9週で $93 \%$ 己結紮前の正常 域内に戻つたことが注目される。

恢復傾向の良い群学選ぶと，光の平均值况 2 週 $36 \%$, 3 週31\%，4 週48\%，6 週54\%，8～9週で65\%であつ t.

GFR も略《同様の傾向示すが，最高恢復伯结 $\mathrm{RPF}$ よりも低く, 正常の下限であつた. 即ち, $2 \sim 3$ 週迄の 結紮でも，若し解除が適正汇われれば，腎機能は徐々 ではあるが予期以上飞推移し，RPF は略々正常迄恢復 可能であり, GFR も，正常下限近く迄恢復してくるこ こが分つた。

此秃対し，一側尿管 5 週以上結㯟では，結㯟側の ERPF, GFR, PSP 共飞解除後 2 週では一㭙的市る程 度の機能恢復を示していたが, 3 週以後の腎機能い零, もしくは需に近く低下していた点が注目される。右の5 週以上結禁で解除後 2 週頃に於ける一時的機能恢復が興 味深いが, 以後腎機能が再び荒廃に陥る点は, Hinman の renal counterbalance 説学肯させるような成績で あつた。

我なは，子宮癌に上る両側尿管狭窄患者の，尿管皮虐 移植後乙れ似を 2 症例安経験している. 即占, 㹨窄解 除後一度注両側督共に可成りの機能を示したものが, 後 に一側腎が機能を殆んで喪失し，対側腎のみが機能を保 持してい症例で, 尿管移植口の狭窄もなく, また, 腎 感染でもこの説明は出来なかつた。

\section{総 括}

Kerr の1 週間尿管結紮実験では, 結紮解除後最高恢 復達するもの活，4〜54日平均21日で，その最高值も 結禁前值の66〜 68\%止りであつて，結紮前值迄恢復する 例怡なかつたし，な2週〜 4週では各 1 例ずつで， ERPF, GFR 共に28～62日後11 42\%間の恢復值であ Dた.

私の実験で柱 $3 \sim 5$ 日尿管結紮群の腎「ク」值沙解除 後 $3 \sim 4$ 週で, GFR, ERPF, PSP 核略々結禁前値に恢 復していを. また $2 \sim 3$ 週結禁でも GFR, ERPF 共に 解除後 $8 \sim 9$ 週に至れば, 結紮前值の平均 $53 \sim 65 \%$ \%恢 
復可能であり, 特に良好な経過を辿つた場合活, 最初 1 週後結禁前值の $20 \%$ 程度を示していたものも, 後には結 㛢前值迄恢復することが分つた。

また, 解除後既に $2 \sim 4$ 週で, GFR, RPF, PSP, TMPAн 共に結紮前值の60\%以上に達する少数例がある 点も注目さ礼る。

勿論しのような機能恢復が, 将来ごのょうに推移して 行く六に就いては, 今後更研究の必要があるが, 何れ にしても, Kerr 等の成績よりほ私の成績の方が良好で 㐫り, 若し, 尿管通過障害の適正な解除が施行され, 術 後の狭窄や腎感染等が発生しない限り，4 週間迄の一側 尿管結禁沙, 解除後数週以内に, 結禁前值の $50 \%$ 内外の 機能恢復学期待出来るここが分つた。

尔た，何時頃腎「ク」值が最高恢復飞達するか比就い て調べると, $3 \sim 5$ 日尿管結紮の最高恢復期は $3 \sim 4$ 週 であり, $2 \sim 3$ 週尿管結禁では, 経過良好の1例より考 えて, 此の結紮期間では, 解除後 9 週迄の追求学北要々 する事が分つた。一方，5週以上の尿管結㨞では，解 除後 2 週頃一㭙的々機能が恢復するが, 以後所謂 late atrophy に陥り，機能褧失に至る傾向が大である事は大 いに注目を要する点であるろ。

次に, 尿管結紮解除後の GFR, ERPF, TmPAH 及び PSP の相互関係就いてみると, Kerr 注何れも平均して経過するという。私の笑験でも GFR と $\mathrm{ERPF}$ その他は略及平行的に恢復していた。 然し, 一般に ERPF 或は TmPAH 及び PSP の方が， GFR に比して恢復程度が大, 且つ恢復に要する目数も短いよ ろであつた.

対側腎「ク」值は結紮側珡の機能低下或以上昇に呼応 して代償性红機能増進するとと注，Kerr，渡井及び筆者 の実験共に同様であつた。な扛, Kerr は，尿管結禁解 除後 2 日で, 対側腎摘出術を行つている. とれによると 一側尿管 $3 \sim 4$ 週結禁例でも, 対側䇾摘出後22日で, 結 禁解除側の GFRは $95 \%$, ERPF は $90 \%$ の最高恢復值を 示している(対側腎摘出術学行なわなかつ学場合に比 する己 GFR は 4.3倍, ERPF は8 倍の值宋してい る).

渡井も1例ではあるが, 一側尿管 3 週結禁犬について も同様の傾向を認めている.

此の様に, 尿管結紮解除後, 結禁側の腎機能が可成り低 下を示しても, 対側腎摘出術を行うことにより驚くべき 機能增進をみることほ前述の如く renal counterbalance 説として有名である。
然し乍ら, 私の実験では，3 頭の一側尿管 5 週間結紮 犬で, 解除後 $2 \sim 8$ 週に於て, 対側腎摘出術学行つた が， 3 例共に術後数日以内に死亡した事学附記してお $<$.

最後に, 尿管結禁解除後の ERPF, GFR と, その他 の検查成績との関連について検討するに, 尿管結禁解除 後の腎「ク」值が正常化しても, なお, 他の検查成績 (尿 $\mathrm{pH}, \mathrm{NH}_{3}$, 尿濃縮能, $\Delta \mathrm{t}$ 等) 正常に復していない 事む少くな分つた。

逆に，腎「ク」值が未だ可なりの低值であるに拘ら ず，静脈性腎盖撮影姃々る造影郕排泄機能が極めて良好 であつた例も可なりあつた（近年 I.Pで正常腎典像学得 ても, 腎のクリアランス或は, 腎血流量は可なり低下し ている事が稀でない事が各種腎疾患並びに腎血管病変に 就いて諸家により論及されている).

\section{結論}

大28頭を用いて, 一側尿管結禁解除（尿管皮膚移植術 による) 後の腎機能恢復過程を, 主として腎クリアラン ス法により観察した。

1. 一側尿管 5 日以内の結紮例では, 解除後 $3 \sim 4$ 週 で, 略く結紮前值に恢復した。

2. $2 \sim 3$ 週結禁例では，解除後の尿管皮膚移植口の 狭窄や腎感染が防止されれば，時と共に腎機能は恢復に 向い, 解除後 $8 \sim 9$ 週で, Csts 沙平均 $53 \%, \mathrm{C}_{\mathrm{PAH}}$ は $65 \%$ 迄に恢復する。

3.乙れに対し, 5 週以上の結紮例では, 解除後 2 週 頃一時的漌办の恢復を示すとこもあるが, 以後腎機能: は結局荒廃に陌つて了つた。

擱筆するに当たり，終始御懇篤なる御指導と御校閲を 賜つた恩師辻一郎教授に, 表心より感謝致します。

\section{文献}

1) Blake, W.D.: Am. J. Physiol., 191, 393, 1959.

2) Brun, C.: J. Lab. Cl. Med., 35, 152, 1050.

3) Davis, D.: Mechanism of Urologic Disease, W.B. Saunders Co. 1953, Philadelphia.

4) Davis, D.: Ann. Surg., 140, 839, 1954.

5) Hamburger, et al.: Ann. Biol. Clin., 6, 358,. 1948.

6) Harrow, B.D.: Am. J. Surg., 87, 842, 1954.

7）橋本虎六: 日薬誌, $39,554,1943$.

8）福井定光: 日本臨床, 14, 961, 1956.

9）藤倉一夫 : 東京医学会誌, 47, 1933.

10) Hinman, F.: Surgery, 17, 816, 1945. 
11) Hinman, F.: J. Urol., 3, 147, 1919.

12) Hinman, F.: Arch. Surg., 12, 1105, 1926.

13) Hinman, F.Jr.: Campbell's Urology, W.B. Saunders Co., 1954, Philadelphia.

14) Holder, E.: Dtsch. Med. Wschr., 81, 1192, 1956.

15) Houck, R.C.: Am. J. Phisiol., 153, 169, 1948.

16) Joelson, J., C. Beck \& A. Morwitz: Arch. Surg., 19, 673, 1929.

17) Johnson, R.A.: J. Exper. Med., 28, 193, 1918.

18）壁島美雄 : 東京医学会誌, 42, 1928.

19）川添重朗：東京医学会誌，44，1930.

20) Kerr, W.S. Jr.: J. Appl. Physiol., 6, 762, 1954.

21) Kerr, W.S. Jr.: Am. J. Physiol., 184, 521, 1956.

22) Kerr, W.S. Jr.: J Urol., 80, 205, 1958.

23）楢原憲音 : 泌尿紀要，3，721，1957.
24) Norman Kalant, C.S. Mc Arthur: J. Lab. C1. Med., 35, 836, 1950.

25）岡直友: 泌尿紀要, 5, 67, 1959.

26）大越正秋，戸田百年：日泌尿会誌，43，255, 1952.

27）大島研三：日本臨床，9，575，1951.

28) Rhoads, C.P., A.S. Aliving, A. Hiller. \& D. D. Van Slyke: Am. J. Physiol., 109, 329, 1934.

29) Selkurt, E.E., M. Brandfonbrener \& H.M. Geller: Am. J. Physiol., 170, 61, 1952.

30) Share, L.: Am. J. Physiol., 168, 97, 1952.

31）富永敛三郎：東京医学会誌，44, 1930.

32) 辻一郎 : 腎臓病学, (腎の㴕留腫), 医学書院, 1959.

33) Walters, W.: Z. Urol. Chir., 36, 265, 1933.

34）渡井幾男：日泌尿会誌，48，721，1957.

35）渡井幾男：日泌尿会誌，48，970，1957. 